\title{
ISOLASI DAN IDENTIFIKASI BAKTERI ASAM LAKTAT INDIGENOUS DARI FERMENTASI ALAMI BIJI KAKAO SEBAGAI KANDIDAT AGEN ANTIKAPANG
}

\author{
Nurul Isnaini Fitriyana*, Sony Suwasono*, dan Joni Kusnadi** \\ * Fakultas Teknologi Pertanian, Universitas Jember, Jember \\ ** Fakultas Teknologi Pertanian, Universitas Brawijaya, Malang \\ E-mail : nurulis_fitriyana@yahoo.com
}

\begin{abstract}
This research have focused on isolation and identification of lactic acid bacteria (LAB) with potential antifungal which candidate as biopreservative microorganisms. LAB produce bioactive compound with antifungal activity. Thus, of a total of 69 lactic acid bacteria isolated and 39 isolates further tested its antifungal activity. Indigenous moulds that will be tested for antifungal activity of LAB were obtained from unfermented cocoa beans. There were black mould (allegedly Aspergillus niger), green mould (allegedly Aspergillus fumigatus) and grayish white mold (allegedly Mucor spp.). Thus, 18 isolates of $L A B$ that could inhibit all of three types of fungi further identified in a phenotype, 3 isolates of LAB with highest antifungal activity in identification with API 50 CHL method and identified as Lactobacillus fermentum, with a different value of ID value, ID 99,8\% (F1L-6an) criteria : very good identification; ID 99.9\% (F1L-6dsr), criteria : very good identification, and ID $89.8 \%(F 3 L-7 P)$ criteria : very good identification to the genus . $L A B$ isolates obtained can be used as starter cultures to improve the quality of fermentation to inhibit the growth of mould, mycotoxin production, and fungicide residues so as to improve quality, safety of cocoa concumption, and increase the price of Indonesian cocoa bean exports.
\end{abstract}

Key words : cacao fermented, lactic acid bacteria, antifungal, API 50 CHL

\section{PENDAHULUAN}

Indonesia merupakan negara penghasil kakao ketiga terbesar di dunia setelah Pantai Gading dan Ghana. Namun tingginya tingkat produksi kakao Indonesia belum diimbangi tingkat kualitas biji kakao. Kualitas yang rendah ini disebabkan tingginya prosentase biji kakao kering yang terserang kapang sehingga menyebabkan tingginya kandungan mikotoksin. Penyebab utama masalah ini adalah proses fermentasi yang kurang optimal. Untuk mengatasi biji kakao kering yang terserang kapang, biasanya dilakukan penyemprotan menggunakan fungisida sehingga menyebabkan tingginya residu fungisida, akibatnya biji kering yang diekspor akan terkena denda atau potongan harga (automatic detention).

Proses fermentasi berperanan penting dalam menentukan kualitas biji kakao. Karena selama proses ini berlangsung, berbagai mikroba alami tumbuh dan berkembang menyebabkan perubahan fisikokimia sehingga didapatkan biji kakao kering yang bermutu tinggi (Wahyudi dkk., 2009). Mikroba yang mempunyai peran penting adalah bakteri asam laktat (BAL) yang merupakan mikroba pengawet alami (biopreservative microorganism) yang menghasilkan metabolit sekunder yang bersifat antimikroba. Lavermicocca et al, 2003 berhasil mengisolasi komponen antikapang, phenyllactic acid (PLA) dan 4hydroxyphenyllactic acid dari Lactobacillus plantarum.

Berdasarkan latar belakang diatas maka dilakukan penelitian ini untuk memperoleh isolat $\mathrm{BAL}$ indigenous dari fermentasi alami biji kakao yang berpotensi sebagai agen antikapang serta mengidentifikasinya. Selanjutnya isolat BAL ini dapat diaplikasikan sebagai starter untuk 
fermentasi dan re-fermentasi biji kakao kering yang belum difermentasi (unfermented).

\section{METODE}

\section{Bahan}

Bahan yang digunakan dalam penelitian ini adalah biji dan lendir kakao terfermentasi alami yang diperoleh dari PTPN XII Kebun Banjarsari Jember. Media MRS (de Man Rogosse Sharp)-Agar dan MRS Broth (Merck), MEA (Merck) dari Laboratorium Mikrobiologi Pangan dan Hasil Pertanian, Fakultas Teknologi Pertanian Universitas Jember. Bahan kimia yang digunakan antara lain $\mathrm{CaCO}_{3}$, akuades, $\mathrm{KOH}$ $3 \%$, gram staining, pewarna malakit hijau, $\mathrm{H}_{2} \mathrm{O}_{2} 3 \%$, alkohol $70 \%$, dari Laboratorium Biokimia dan Kimia Hasil Pertanian Fakultas Teknologi Pertanian Universitas Jember serta Kit API 50 CHL (bioMerieux, Perancis) yang terdiri dari media API 50 CHL, mineral oil, standard Mc Farland no.2; dari Laboratorium Sentral Ilmu Hayati (LSIH), Universitas Brawijaya, Malang

Alat yang digunakan dalam dalam penelitian ini adalah laminar air flow (crumair, tipe 9005FL), cawan petri, anaerobic candle jar, kit anaerob (Anaerobicult, Merck), inkubator suhu $37^{\circ} \mathrm{C}$ (Heraeus tipe B-6200), mikropipet, mikropipet tip, tabung Eppendorf volume 1.5 $\mathrm{ml}$, neraca analitik (Denver Instrument Company, tipe AA200DS), thermometer, $\mathrm{pH}$ meter (Hanna), mikroskop, gelas obyek, gelas penutup, jarum ent, jarum ose, bunsen.

Isolasi Bakteri Asam Laktat (BAL) dari Biji dan Lendir Kakao Terfermentasi

Metode isolasi yang digunakan adalah metode pengenceran yang dilanjutkan dengan inokulasi secara pour plate. Inkubasi secara anaerobik dalam candle anaerobic jar pada suhu $37^{\circ} \mathrm{C}$ selama $24-48$ jam dan ditambahkan kit anaerob. Koloni dari kelompok BAL akan menunjukkan area bening disekitarnya karena reaksi asam organik yang diproduksi BAL dengan $\mathrm{CaCO}_{3}$ pada media MRS Agar. Selanjutnya koloni digoreskan kembali ke medium MRS Agar dengan goresan kuadran berulang-ulang sampai didapatkan koloni yang seragam. Selanjutnya koloni yang telah murni dipilih untuk diuji aktivitas antikapangnya.

\section{Isolasi Kapang dari Biji Kakao Kering}

Kapang target untuk menguji sifat antikapang isolat BAL menggunakan sampel biji kakao kering jenis lindak (bulk) berasal dari PT Hajji Naga, Makassar, Sulawesi Selatan yang terkontaminasi kapang. Biji kakao yang terkontaminasi kapang di letakkan di atas cawan petri berisi media Malt Extract Agar (MEA), dan diinkubasi pada suhu $30^{\circ} \mathrm{C}$ selama $4-6$ hari. Tiap jenis kapang yang tumbuh kemudian digoreskan kembali pada media MEA berulang kali sampai didapatkan kultur yang murni dengan warna miselium yang sama.

\section{Aktivitas Antikapang Kultur BAL}

Pengujian aktivitas antikapang dari kultur bakteri asam laktat (BAL) dilakukan dengan metode Difusi Sumur (modifikasi Agar Well Diffusion Method, Schnurer dan Magnusson, 2001)). Suspensi kapang target ditumbuhkan pada media MEA. Kemudian, dibuat sumuran dengan diameter sekitar $4-5$ mm menggunakan alat cork borer yang steril, dua kali ulangan dan satu sumuran sebagai kontrol.

Pengujian dilakukan dengan memipet 40 - $50 \mu \mathrm{L}$ suspensi kultur BAL dan dituangkan dalam masing-masing sumur, dibiarkan selama \pm 3 - 4 jam hingga meresap. Inkubasi pada suhu $37^{\circ} \mathrm{C}$ selama 48 jam, tanpa dibalik. Satu sumur sebagai kontrol hanya diisi dengan $40-50 \mu \mathrm{L}$ media MRS Broth saja. Aktivitas antikapang dapat diamati dengan melakukan pengukuran diameter daerah bening (tidak ditumbuhi kapang) di sekitar sumur menggunakan jangka sorong. Luas daerah bening disekitar sumuran ditentukan sebagai efek penghambatan BAL terhadap kapang yang diuji. BAL yang dilih untuk diidentifikasi lebih lanjut adalah BAL yang mempunyai aktivitas antikapang atau mampu menghambat seluruh kapang yang di ujikan.

\section{Identifikasi Bakteri Asam Laktat \\ a. Pewarnaan Gram (Bell et al., 2005)}

Aquades steril di tetes kan diatas gelas obyek kemudian ditambahkan 1 ose bakteri umur 48 jam dan diratakan pada permukaan atas gelas obyek. Selanjut nya preparat difiksasi hingga terbentuk noda. Di atas noda tersebut diteteskan pewarna kristal violet (gram A) dan dibiarkan selama 1 menit kemudian di cuci dengan air mengalir dan 
dikeringanginkan. Selanjutnya ditetesi dengan larutan mordan atau lugol (gram B) dan dibiarkan selama 1 menit kemudian dicuci dengan air mengalir dan dikeringanginkan. Tahap selanjutnya adalah ditetesi dengan alkohol-aseton (gram C) sampai cat luntur dan tidak berwarna. Tahap terakhir dari pengecatan gram ini adalah ditetesi dengan pewarna safranin (gram D) selama 30 detik, kemudian dicuci dengan air mengalir dan dikeringanginkan. Objek glass ditutup dengan deck glass dan diamati di bawah mikroskop dengan perbesaran $1000 x$. Isolat $\mathrm{BAL}$ menunjukkan warna ungu dibawah mikroskop.

\section{b. Uji Katalase (Bell et al., 2005)}

Aquades steril di tetes kan diatas gelas obyek kemudian ditambahkan 1 ose bakteri umur 48 jam dan diratakan pada permukaan atas gelas obyek lalu ditetesi dengan $\mathrm{H}_{2} \mathrm{O}_{3} 3 \%$, didiamkan selama 1 menit. Apabila timbul gelembung udara menunjukan katalase positif dan apabila tidak timbul gelembung udara menunjukan katalase negatif.

\section{c. Pewarnaan Endospora (Bell et al., 2005)}

Gelas obyek dan gelas penutup dibersihkan menggunakan etanol 70\% kemudian dikeringanginkan. Akuades steril di tetes kan diatas gelas obyek kemudian ditambahkan 1 ose bakteri umur 72 jam dan diratakan pada permukaan atas gelas obyek dengan luas sekitar $1.5 \times 1.5 \mathrm{~cm}^{2}$. Preparat di fiksasi dengan melewatkannya diatas nyala api bunsen beberapa kali. Preparat yang sudah di fiksasi digenangi dengan pewarna malakit hijau dan dipanaskan diatas penangas air (diatas air mendidih) hingga timbul uap air ( \pm 10 menit) (dijaga agar pewarna jangan sampai kering), kemudian dicuci dengan air mengalir dan dikeringanginkan. Preparat diamati menggunakan mikroskop (perbesaran 1000x) untuk mengetahui adanya spora dalam sel (endospora). Isolat BAL akan menunjukkan tidak ada spora dalam sel.

d. Identifikasi Bakteri Asam Laktat Level Spesies dengan Metode API 50 CHL Identifikasi bakteri asam laktat

(BAL) dapat dilakukan berdasarkan kemampuannya memfermentasi karbohidrat dalam 50 tes biokimia menggunakan kit API 50 CHL.
Tiga (3) ose koloni tunggal dari MRS Agar dalam cawan petri dimasukkan kedalam 2 ml larutan $\mathrm{NaCl} 0.85 \%$ steril dalam tabung reaksi, kemudian dihomogenisasi menggunakan vortex. Selanjutnya dari tabung ini diteteskan perlahan ke dalam tabung reaksi lain yang berisi $5 \mathrm{ml} \mathrm{NaCl} 0.85 \%$ steril sampai kekeruhannya sama dengan kekeruhan pada standard Mc Farland no.2. Kemudian dimasukkan ke dalam media API 50 CHL. Setelah dihomogenisasi, media API $50 \mathrm{CHL}$ dimasukkan ke dalam strip-strip mikrotube secara hati-hati, dijaga agar jangan sampai ada gelembung udara didalam mikrotube. Ujung mikrotube yang telah diisi dengan media API 50 CHL ditetesi dengan 2 tetes mineral oil. Selanjutnya tray ditutup dan diinkubasi pada $37^{\circ} \mathrm{C}$ selama 48 jam. Perubahan warna yang terjadi pada tiap-tiap mikrotube diamati pada 24 jam dan 48 jam. Hasil pengamatan dimasukkan ke dalam software APIweb untuk kemudian ditentukan spesies dari BAL tersebut.

\section{HASIL DAN PEMBAHASAN}

\section{Isolasi Bakteri Asam Laktat dari Fermentasi Alami Biji Kakao}

Fermentasi alami biji kakao berlangsung selama 4 hari di dalam kotak kayu (tray fermentation). Satu unit kotak fermentasi terdiri dari 4 kotak kayu yang disusun secara bertingkat. Pengambilan sampel biji dan lendir kakao terfermentasi dilakukan setiap hari di beberapa titik, satu titik bagian tengah dan dua titik di bagian pinggir kotak dengan kedalaman sekitar $10-15 \mathrm{~cm}$.

Dari fermentasi biji kakao ini berhasil di isolasi sebanyak 69 isolat yang diduga bakteri asam laktat (BAL).Isolat BAL yang berhasil diisolasi bervariasi, berasal dari biji maupun dari bagian lendir kakao, dengan tipe pertumbuhan koloni dipermukaan media, di bagian dalam media, dan dibagian dasar media MRS Agar dalam cawan petri. Berikut adalah tabel total bakteri asam laktat (BAL) dari biji dan lendir kakao terfermentasi selama 4 hari fermentasi. 
Tabel 1. Total Bakteri Asam Laktat (BAL) dari Biji dan Lendir Kakao Terfermentasi

\begin{tabular}{|c|c|c|c|c|c|c|}
\hline \multirow{2}{*}{$\begin{array}{l}\text { FER } \\
\text { MENTASI } \\
\text { HARI KE- }\end{array}$} & \multicolumn{3}{|c|}{$\begin{array}{c}\text { BIJI } \\
\text { (CFU/g) }\end{array}$} & \multicolumn{3}{|c|}{$\begin{array}{l}\text { LENDIR } \\
\text { (CFU/g) }\end{array}$} \\
\hline & Permukaan* & Dalam^^ & Dasar• & Permukaan* & Dalam^^ & Dasar• \\
\hline $0(F 0)$ & $1.22 \times 10^{3}$ & $1.02 \times 10^{3}$ & $2.02 \times 10^{3}$ & $2.18 \times 10^{3}$ & $1.31 \times 10^{3}$ & $2.61 \times 10^{3}$ \\
\hline $1(F 1)$ & $2.95 \times 10^{6}$ & $1.87 \times 10^{7}$ & $2.47 \times 10^{7}$ & $2.06 \times 10^{7}$ & $2.87 \times 10^{7}$ & $2.57 \times 10^{7}$ \\
\hline 2 (F2) & $2.37 \times 10^{4}$ & $2.58 \times 10^{5}$ & $1.61 \times 10^{5}$ & $1.10 \times 10^{5}$ & $1.93 \times 10^{5}$ & $1.93 \times 10^{5}$ \\
\hline $3(F 3)$ & $2.11 \times 10^{4}$ & $1.44 \times 10^{5}$ & $2.27 \times 10^{5}$ & $2.64 \times 10^{4}$ & $1.73 \times 10^{5}$ & $2.33 \times 10^{5}$ \\
\hline 4 (F4) & $2.63 \times 10^{3}$ & $1.20 \times 10^{3}$ & $2.22 \times 10^{3}$ & $2.12 \times 10^{3}$ & $2.94 \times 10^{3}$ & $2.45 \times 10^{3}$ \\
\hline
\end{tabular}

Berdasarkan Tabel 1. diatas dapat dilihat bahwa isolat BAL terdapat pada biji dan lendir kakao terfermentasi selama 4 hari fermentasi. Kelompok BAL terlihat paling sedikit pada tahap awal fermentasi (F0), kemudian menjadi dominan pada tahap akhir dari fermentasi hari ke-1 (F1). Populasi kelompok BAL selanjutnya mengalami penurunan pada fermentasi hari ke-2 (F2), ke3 (F3) dan semakin menurun pada hari ke-4 (F4)

Pada awal fermentasi mikrobiota didominasi oleh kelompok khamir.Pulp kakao merupakan media yang baik untuk pertumbuhan khamir. Menurut Ardhana dan Fleet (2003), komposisi pulp menentukan keberhasilan proses fermentasi. Oleh karena itu buah kakao yang dipetik adalah buah kakao yang telah matang sempurna di pohon. Pulp pada buah yang yang belum matang banyak mengandung sukrosa, sedangkan pada buah kakao matang didominasi oleh glukosa dan fruktosa. Glukosa dan fruktosa adalah monosakarida yang mudah digunakan sebagai substrat untuk pertumbuhan khamir. Khamir akan memetabolisme gula menjadi alkohol dan $\mathrm{CO}_{2}$ dalam reaksi eksotermis yang menghasilkan panas. Selanjutnya kondisi lingkungan yang anaerob dan suhu yang meningkat menyebabkan kelompok bakteri asam laktat (BAL) akan mengambil alih dominasi pertumbuhan. BAL akan memetabolisme gula menjadi asam laktat dan asam-asam organik lainnya.

Isolat yang didapatkan (69 isolat) digoreskan kembali (re-streaking) pada media MRS Agar dengan goresan kuadran. Pemurnian dilakukan sebanyak dua (2) kali sampai didapatkan koloni tunggal dengan kenampakan yang sama. Setelah tahap pemurnian didapatkan 39 isolat dengan pertumbuhan yang bagus, selanjutnya 39 isolat ini diuji aktivitas antikapangnya dan dipilih lagi sebanyak 18 isolat BAL yang mempunyai sifat antikapang tertinggi, kemudian diuji secara fenotiP. Pemberian kode isolat berdasarkan asal isolat, lama fermentasi, tingkat pengenceran, dan letak pertumbuhannya pada media MRS Agar. Misal nya F1L-6 dsr : isolat dari fermentasi kakao hari ke-1, diisolasi dari lendir (pulp) kakao, dari hasil inokulasi suspensi pada tingkat pengenceran $10^{-6}$, dan letak pertumbuhannya di dasar atau di bagian bawah media MRS Agar pada cawan petri.

\section{Isolasi Kapang dari Biji Kakao Kering Tidak Terfermentasi (unfermented) yang Terserang Kapang}

Kapang target diisolasi dari biji kakao kering asal PT Hajji Naga, Makassar, Sulawesi Selatan. Setelah melalui pemurnian, maka diperoleh 3 spesies kapang dominan Selanjutnya dilakukan pengamatan secara visual kapang yang ditumbuhkan pada media MEA dalam cawan petri kemudian dibandingkan dengan kunci identifikasi dari "Mycology BookWEB" dari Anonymous, 2010, maka kapang yang dominan menyerang biji kakao kering diduga adalah Mucor spp. (berwarna putih keabuan), Aspergillus fumigatus (berwarna hijau) dan Aspergillus niger (berwarna hitam). Seperti yang dilaporkan Betina, dalam Cahyaningsih (2006) kapang patogen yang umumnya menyerang biji kakao adalah Aspergillus flavus, Aspergillus niger, Penicillium, dan Mucor spp. Demikian juga seperti halnya dalam penelitian Bunting (1928); Dade (1928); Roelofsen dan Giesberger (1947); 
Maravalhas (1966); Lehrian dan Patterson (1983); serta Nielsen (2006) kelompok kapang dominan yang menyerang biji kakao adalah Aspergillus fumigatus dan Mucor spp.

\section{Aktivitas Antikapang}

Aktivitas antikapang isolat BAL dapat diamati dengan mengukur diameter daerah bening di sekitar sumuran yang tidak ditumbuhi kapang, dan dihitung secara matematis menjadi luas daerah bening (penghambatan). Hasil pengukuran daerah bening dapat dilihat pada Tabel 2 .

Berdasarkan Tabel 2, isolat BAL yang berasal dari tahap awal fermentasi (F0) ternyata tidak mampu menghambat ketiga jenis kapang. Bahkan isolat BAL yang diisolasi dari lendir kakao tidak mempunyai kemampuan menghambat ketiga jenis kapang. Isolat BAL dari fermentasi kakao hari ke-1 (F1) menunjukkan aktivitas antikapang yang cukup besar. BAL dari fermentasi kakao hari ke-2 (F2) secara umum mengalami penurunan aktivitas antikapang dibandingkan isolat $\mathrm{BAL}$ dari F1. Dari 5 isolat yang diuji, dipilih 2 isolat yang akan diidentifikasi. Isolat $\mathrm{BAL}$ dari fermentasi kakao hari ke-3 mengalami peningkatan aktivitas antikapang kembali. Dari 11 isolat yang diuji aktivitas antikapangnya dipilih 8 isolat dengan aktivitas antikapang lebih besar daripada yang lain. Selanjutnya 9 isolat BAL dari fermentasi kakao hari ke-4 yang diuji, dipilih 3 isolat untuk diidentifikasi. Sehingga berdasarkan aktivitas antikapang nya, dari 39 isolat BAL yang diuji dipilih 18 isolat BAL dengan aktivitas antikapang yang besar untuk diidentifikasi.

Kemampuan beberapa isolat yang berbeda terhadap 3 kapang yang diujikan dapat dilihat pada Gambar 1. Dari Gambar 1. dapat dilihat bahwa kemampuan isolat BAL dalam menghambat kapang berbeda-beda tergantung pada spesies BAL. Spesies BAL yang berbeda akan menghasilkan penghambatan dan aktivitas yang berbeda karena perbedaan metabolit yang dihasilkan.
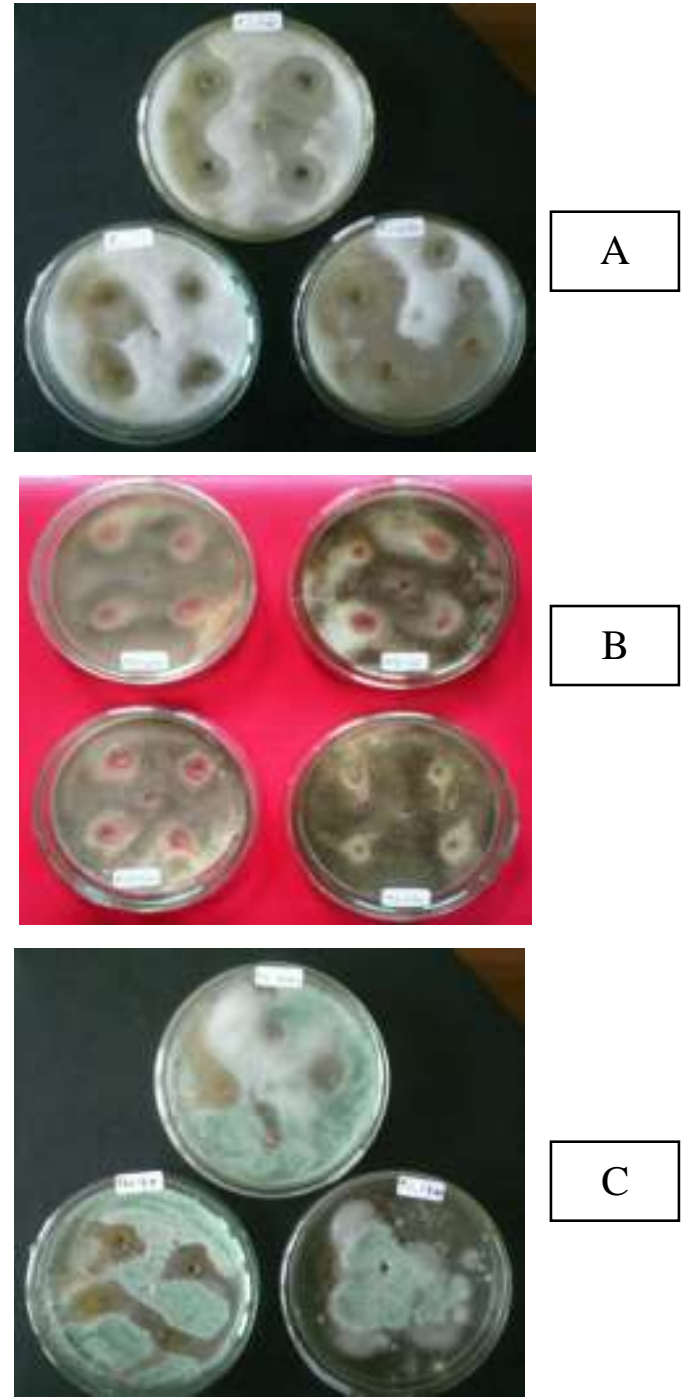

Gambar 1. Aktivitas Antikapang isolat BAL terhadap kapang putih (A); kapang hitam (B); dan kapang hijau (C).

Hasil pengujian aktivitas antikapang yang dinyatakan dalam luas daerah penghambatan menunjukkan bahwa kemampuan isolat BAL dalam menghambat kapang berbeda-beda tergantung pada spesies BAL. Spesies BAL yang berbeda akan menghasilkan penghambatan dan aktivitas yang berbeda karena perbedaan metabolit yang dihasilkan. 
Tabel 2. Hasil Pengukuran Luas Daerah Penghambatan Isolat BAL terhadap Pertumbuhan Kapang Target

\begin{tabular}{|c|c|c|c|c|c|c|}
\hline$F$ & KODE ISOLAT & $\begin{array}{l}\text { Kapang } \\
\text { Hitam } \\
\left(\mathrm{cm}^{2}\right)\end{array}$ & $\begin{array}{c}\text { Kapang } \\
\text { Hijau } \\
\left(\mathrm{cm}^{2}\right)\end{array}$ & $\begin{array}{c}\text { Kapang } \\
\text { Putih-abu } \\
\left(\mathrm{cm}^{2}\right)\end{array}$ & $\begin{array}{l}\text { Rata } \\
\text { Rata } \\
\left(\mathrm{cm}^{2}\right)\end{array}$ & $\begin{array}{c}\text { Skor } \\
\text { Antikapang }\end{array}$ \\
\hline \multirow[t]{2}{*}{ Fo } & 1. FO-6B P & 0.7850 & 0.0000 & 0.0000 & 0.2617 & + \\
\hline & 2. FO-6L P & 0.0000 & 0.0000 & 0.0000 & 0.0000 & - \\
\hline \multirow[t]{12}{*}{ F1 } & 3. F1 L-6 an & 0.6218 & 1.6505 & 0.0000 & 0.7574 & + \\
\hline & 4. F1 L-5 P & 0.0000 & 1.5386 & 0.0000 & 0.5129 & + \\
\hline & 5. F1 L-6 P & 1.3886 & 0.0000 & 0.0000 & 0.4629 & + \\
\hline & 6. F1 L-5 an & 0.5874 & 1.3267 & 11.0391 & 4.3177 & +++++ \\
\hline & 7. F1 L-5 dsr & 0.7850 & 2.2687 & 3.6965 & 2.2500 & +++ \\
\hline & 8. F1 L-6 an* & 0.7085 & 1.0382 & 0.0000 & 0.5822 & + \\
\hline & 9. F1 L-6 an ** & 1.6848 & 4.9063 & 6.8315 & 4.4742 & +++++ \\
\hline & 10. F1 L-6 dsr & 2.3494 & 8.5487 & 1.8860 & 4.2613 & +++++ \\
\hline & 11. F1 L-6P* & 2.4732 & 0.0000 & 0.0000 & 0.8244 & + \\
\hline & 12. F1L-5 an* & 0.6010 & 4.7120 & 0.5343 & 1.9491 & ++ \\
\hline & 13. F1L-6 an *** & 1.7079 & 0.0000 & 0.0000 & 0.5693 & + \\
\hline & 14. F1 L-6 $p^{*}$ & 1.5386 & 0.0000 & 0.0000 & 0.5129 & + \\
\hline \multirow[t]{5}{*}{ F2 } & 15. F2 B-6 dsr & 0.9759 & 0.0000 & 0.0000 & 0.3253 & + \\
\hline & 16. F2 B-6 $p$ & 1.1304 & 0.0000 & 0.0000 & 0.3768 & + \\
\hline & 17. F2 B-6 an & 1.6278 & 1.8860 & 0.0000 & 1.1712 & ++ \\
\hline & 18. F2 B-5p & 0.6359 & 2.2687 & 0.8655 & 1.2567 & ++ \\
\hline & 19. F2 L -6p & 0.7850 & 0.0000 & 0.9847 & 0.5899 & + \\
\hline \multirow[t]{11}{*}{ F3 } & 20. F3 L-7 an & 3.4619 & 1.2070 & 0.6079 & 1.7589 & ++ \\
\hline & 21. F3 L-7 p & 1.3267 & 4.9063 & 0.0000 & 2.0776 & +++ \\
\hline & 22. F3 L -7 $p^{*}$ & 1.7663 & 4.5973 & 5.3066 & 3.8900 & ++++ \\
\hline & 23. F3 B-7 dsr & 0.6359 & 0.0000 & 0.0000 & 0.2120 & + \\
\hline & 24. F3 L-5p & 1.1304 & 0.0000 & 0.0000 & 0.3768 & + \\
\hline & 25. F3 B-7 $p$ & 1.2861 & 0.6010 & 10.6019 & 4.1630 & +++++ \\
\hline & 26. F3 B-7 $p^{*}$ & 0.9072 & 0.4776 & 1.1023 & 0.8290 & + \\
\hline & 27. F3 B-7 an & 1.1493 & 1.6505 & 6.6019 & 3.1339 & ++++ \\
\hline & 28. F3 L -7 dsr & 2.4872 & 2.9850 & 3.7994 & 3.0905 & ++++ \\
\hline & 29. F3 L-7 an * & 0.5024 & 1.7663 & 7.7152 & 3.3279 & ++++ \\
\hline & 30. F3 L-7 an ** & 1.5386 & 0.0000 & 3.7994 & 1.7793 & ++ \\
\hline \multirow[t]{9}{*}{ F4 } & 31. F4 L-7 an & 0.0000 & 2.4041 & 0.4715 & 0.9585 & + \\
\hline & 32. F4 B-5 an & 0.0000 & 0.0000 & 0.5672 & 0.1891 & + \\
\hline & 33. F4 B-5 an* & 0.0000 & 0.0000 & 0.3419 & 0.1140 & + \\
\hline & 34. F4 B-6 an & 0.0000 & 2.0729 & 3.0620 & 1.7116 & ++ \\
\hline & 35. F4 B-5 p & 0.7085 & 0.0000 & 0.0000 & 0.2362 & + \\
\hline & 36. F4 B-6 dsr & 0.0000 & 0.0000 & 2.4041 & 0.8014 & + \\
\hline & 37. F4 L-5 dsr & 0.3847 & 0.0000 & 1.1780 & 0.5209 & + \\
\hline & 38. F4 B-6dsr* & 1.1780 & 0.0000 & 5.5127 & 2.2302 & +++ \\
\hline & 39. F4 B-6 $p$ & 1.8860 & 2.7568 & 2.1631 & 2.2686 & +++ \\
\hline
\end{tabular}


Ada kelompok BAL yang hanya menghasilkan metabolit berupa asam laktat saja dan ada kelompok BAL yang selain menghasilkan asam laktat juga menghasilkan asam-asam organik lainnya. Menurut Salminen et al. (2004), kelompok BAL yang hanya menghasilkan asam laktat (90\%) termasuk dalam kelompok BAL homofermentatif, biasanya banyak diaplikasikan sebagai pengawet alami (biopreservative agents) terutama dalam pengawetan makanan, karena kemampuannya menghasilkan asam laktat dalam jumlah tinggi yang mampu menghambat pertumbuhan bakteri pembusuk dan patogen dalam makanan. Sedangkan kelompok BAL yang menghasilkan asam laktat dan asam-asam organik lainnya termasuk dalam kelompok heterofermentatif Spesies Leuconostoc, Lactobacillus fermentum, Lactobacillus buchneri, Lactobacillus brevis, termasuk dalam kelompok BAL heterofermentatif (Sharpe, 1986).

Beberapa penelitian menunjukkan bahwa BAL menghasilkan senyawa antikapang antara lain asam laktat, asam asetat, asam kaproat, asam format, asam fenillaktat, dan asam 4-hidroksifenillaktat, dipeptida siklik seperti siklo (Gly-L-Leu), siklo (L-Phe-LPro), dan siklo (L-Phe-trans-4OH-L-Pro), asam benzoat, methilhidantoin, mevanolakton, asam lemak berantai pendek, senyawa protein dngan BM rendah, bakteriosin, hydrogen peroksida (Lavermicocca et al., 2000; Storm et al., 2002; Fazeli et al., 2004). Dalam penelitian Sjogren et al. (2003) melaporkan bahwa spesies Lactobacillus plantarum MiLAB 14 menghasilkan asam 3-[R]hidroksidodekanoik, asam 3-hidroksi-5-cis dodesenoik, dan asam 3-[R]hidroksitetradekanoik yang bersifat antikapang. Mekanisme penghambatan senyawa metabolit yang dihasilkan oleh beberapa kelompok BAL terhadap kapang belum diketahui secara pasti. Diduga asamasam organik tersebut memiliki aktivitas seperti detergen yang akan mempengaruhi struktur membran sel kapang, yaitu meningkatkan permeabilitas membran dan membebaskan elektrolit serta protein intraseluler yang mengakibatkan disintegrasi sitoplasma sel kapang.

Aktivitas senyawa metabolit antikapang yang dihasilkan oleh BAL tergantung pada $\mathrm{pH}$, hal ini mengindikasikan bahwa aktivitas penghambatan berkaitan dengan karakteristik lipofilik membran sel mikroorganisme yang dapat dilewati oleh senyawa yang bersifat antikapang tersebut.

\section{Identifikasi Isolat Bakteri Asam Laktat dengan Metode API 50 CHL}

Tujuh (7) isolat terpilih dengan aktivitas antikapang paling tinggi (isolat dengan kode F1 L-6 an; F1 L-6 dsr; F3 L-7 p; F3 L-7 dsr; F3 L-7 an; F1 L-5 an; serta F1 L-5 an*) diuji kembali dengan pengujian pewarnaan gram, sifat katalase, dan pewarnaan endospora untuk memastikan bahwa isolat yang akan diidentifikasi lebih lanjut dengan metode API 50 CHL benarbenar merupakan kelompok BAL. Dari tahap ini dipilihlah 3 (tiga) isolat dengan aktivitas antikapang tertinggi yaitu isolat dengan kode : F1L-6an; F1L-6dsr; serta F3L-7p.

$$
\text { Selanjutnya ketiga isolat }
$$

diidentifikasi berdasarkan metode protokol dalam sistem API 50 CHL berdasarkan pada kemampuan bakteri asam laktat untuk memfermentasi karbohidrat. Karbohidrat merupakan sumber karbon dan sumber energi utama untuk pertumbuhan bakteri. Namun setiap spesies bakteri mampu memfermentasi karbohidrat jenis tertentu dan tidak mampu memfermentasi jenis karbohidrat yang lain. Oleh karena itu pengujian kemampuan memfermentaasi karbohidrat dapat digunakan sebagai dasar identifikasi bakteri asam laktat (BAL).

Isolat F1L-6dsr, F1L-6an, serta F3L$7 \mathrm{p}$ teridentifikasi sebagai Lactobacillus fermentum dengan nilai ID dan $\mathrm{T}$ yang berbeda. Isolat F1L-6an teridentifikasi sebagai Lactobacillus fermentum dengan nilai ID 99.8\% dan nilai $\mathrm{T}$ sebesar 1.0; kriteria identifikasi adalah very good identification. Nilai $\mathrm{T}$ (typical index) sebesar 1.0 menunjukkan bahwa semua pola reaksi fermentasi isolat yang diuji cocok (sesuai) dengan profil spesies yang ada di database. 
Isolat F1L-6dsr teridentifikasi sebagai Lactobacillus fermentum dengan nilai ID $99.9 \%$ dan nilai $\mathrm{T}$ sebesar 1.0 dengan kriteria identifikasi adalah excellent identification. Nilai ID isolat F1L-6dsr lebih tinggi daripada isolat F1L-6an menunjukkan bahwa isolat F1L-6dsr mempunyai pendekatan relatif yang lebih baik terhadap profil spesies yang ada database.

Isolat F3L-7p dengan ID $89.8 \%$ dan nilai $\mathrm{T}$ sebesar 0.91 dengan kriteria identifikasi very good identification to the genus. Pada lembar hasil identifikasi terdapat keterangan complementary test $(s)$ yang menunjukkan perlu dilakukan uji pelengkap, karena $9.6 \%$ dari isolat yang diuji teridentifikasi sebagai Lactobacillus buchneri, maka diperlukan uji pelengkap untuk menentukan spesies isolat yang diuji yaitu uji pertumbuhan pada suhu $15^{\circ} \mathrm{C}$ dan $45^{\circ} \mathrm{C}$. Apabila isolat F3L-7p mampu tumbuh pada suhu $15^{\circ} \mathrm{C}$ dan tidak dapat tumbuh pada suhu $45^{\circ} \mathrm{C}$ maka isolat ini adalah Lactobacillus buchneri, namun sebaliknya apabila isolat ini mampu tumbuh pada suhu $45^{\circ} \mathrm{C}$ dan tidak dapat tumbuh pada suhu $15^{\circ} \mathrm{C}$ maka isolat ini adalah Lactobacillus fermentum. Karena isolat ini mampu tumbuh pada suhu $45^{\circ} \mathrm{C}$ tapi tidak dapat tumbuh pada suhu $15^{\circ} \mathrm{C}$ maka isolat ini adalah Lactobacillus fermentum.

Roelofsen dan Giesbenger (1947) ; Ostovar dan Keeney (1973); Carr dan Davies (1980); Passos et al. (1984); Thompson et al. (2001); Ardhana dan Fleet (2003); Schwan dan Wheals (2004); Nielsen (2006); Kostinek et al. (2008) melaporkan bahwa kelompok bakteri asam laktat yang mendominasi fermentasi kakao (baik dengan metode heapfermentation maupun tray fermentation) di negara penghasil kakao di dunia (Cote d'Ivore, Ghana, Indonesia, Nigeria, Malaysia, Brazil, Trinidad, Karibia, India) adalah Lactobacillus fermentum.

Sejauh ini belum ada laporan penelitian mengenai isolasi dan identifikasi Lactobacillus fermentum dari fermentasi kakao yang mempunyai potensi antikapang serta aplikasinya sebagai kultur starter. Fazeli et al. (2004) melaporkan telah mengisolasi Lactobacillus fermentum dari adonan roti pada pembuatan roti secara tradisional di Iran. Isolat Lactobacillus fermentum yang didapatkan mempunyai sifat antikapang yang mampu menghambat pertumbuhan kapang sehingga produk roti yang dihasilkan mempunyai umur simpan yang lebih panjang.

Aplikasi Lactobacillus fermentum sebagai kultur starter masih perlu diteliti lebih lanjut. Beberapa penelitian melaporkan penggunaan khamir sebagai kultur starter dalam fermentasi kakao yaitu Saccharomyces cereviseae (Samah et al., 1992), Saccharomyces theobromae (Dzogbefia et al., 1999). Schwan (1998) melaporkan penggunaan inokulum campuran khamir dan bakteri asam laktat (BAL) sebagai kultur starter yaitu Saccharomyces cereviseae, Lactobacillus plantarum, serta Lactobacillus lactis untuk mengontrol dan meningkatkan kualitas fermentasi kakao.

Isolat BAL yang berhasil diisolasi dan diidentifikasi adalah Lactobacillus fermentum yang berpotensi antikapang. Isolat BAL ini dapat digunakan sebagai kultur starter untuk mengoptimalkan proses fermentasi biji kakao sehingga diperoleh biji kakao yang tahan terhadap serangan kontaminasi kapang. Dengan demikian akan meningkatkan kualitas biji kakao ekspor Indonesia.

\section{KESIMPULAN DAN SARAN}

\section{Kesimpulan}

Isolat BAL dari fermentasi alami biji kakao di PTPN XII Kebun Banjarsari, Jember (F1L-6an; F1L-6dsr, dan F3L-7p) teridentifikasi sebagai Lactobacillus fermentum merupakan kandidat agen antikapang. Isolat BAL ini dapat digunakan sebagai kultur starter untuk proses fermentasi yang lebih optimal dan fermentasi kembali (re-fermentation) biji kakao yang tidak mengalami fermentasi (unfermented). sehingga menekan kontaminasi oleh kapang dan menurunkan kandungan mikotoksin. Dengan demikian keamanan, kualitas, serta harga ekspor biji kakao Indonesia akan meningkat.

\section{Saran}

Isolat BAL yang telah teruji mempunyai sifat antikapang perlu diidentifikasi lebih lanjut dengan metode PCR (Polymerase Chain Reaction) yang mengamplifikasi gen penyandi 16s rRNA, sehingga didapatkan informasi sampai ke 
level strain nya. Serta isolasi dan identifikasi senyawa bioaktif antikapang yang dihasilkannya.

\section{DAFTAR PUSTAKA}

Anonymous ${ }^{\mathrm{a}}$. 2010. Mycology BookWeb. http://www.mycology.adelaide.edu. au.html; diakses pada 21 oktober 2010 .

Ardhana dan Fleet. 2003. The Microbial Ecology of Cocoa Bean Fermentation in Indonesia. International Journal of food Microbiology 86 (2003) p.8799

Bell, C., P. Neaves, A.P. Williams. 2005. Food Microbiology : Laboratory Practice, Blackwell Publishing, USA

Cahyaningsih, H.E. .2006. Identifikasi Bakteri Asam Laktat dari Nira Lontar serta Aplikasinya dalam Mereduksi Salmonellathypimurium dan Aspergillusflavus pada Biji Kakao, Sekolah Pascasarjana Institut Pertanian Bogor, Bogor

Cappucino dan Sherman. 2005. Microbiology : A Laboratory Manual, Dary, The Benjamin/Cummings Publ. Co. Inc. New York

Fazeli MR. 2004. Sourdough-isolated Lactobacillus fermentum as a potent anti-mould preservative of a traditional Iranian bread. Eur Food Res Technol (2004) 218:554-556

Lavermicocca, P., F. Valerio, A. Evidente, S. Lazzaroni, A. Corsetti, and M. Gobbetti. 2000. Purification and characterization of novel antifungal compounds from the sourdough
Lactobacillus plantarum strain $21 \mathrm{~B}$. Appl. Environ. Microbiology.66:40844090.

Lavermicocca, P, F. Valerio, dan A. Visconti. 2003. Antifungal Activity of Phenyllactic Acid Against Mold Isolated From Bakery Products. Applied and Env. Microbiology, Vol $69,1: 634-640$.

Magnusson, J. dan J. Schnurer.Lactobacillus coryniformis subsp. coryniformisStrain Si3 Produces a Broad-Spectrum Proteinaceous Antifungal Compound. Applied and Env. Microbiology, Vol 67, $1: 1-5$.

Nielsen, D.S.2006. The Microbiology of Ghanaian Cocoa Fermentations, Department of Food Science, Food Microbiology The Royal Veterinary and Agricultural University, Denmark

Nielsen,D.S. et.al. 2007. The Microbiology of Ghanaian Cocoa Fermentations Analysed Using Culture-Dependent and Culture-Independent Methods, International Journal of Food Microbiology

Ostovar, K dan P.G Keeney.1973. Isolation and Caracterization of Microorganisms Involved in the Fermentation of Trinidadd's Cacao Beans.Journal of Food Science, 38.

Passos, P.M.L., D.O. Silvia, A. Lopez, C.L.F. Ferreira, dan W.V. Guimaraes. 1984. Characterization and Distribution of Lactic Acid Bacteria From Traditional Cocoa Bean Fermentation in Bahia. J. Food Sci. 49. 